\title{
The State of Higher Education in the Dominican Republic
}

\author{
Clifford Jaylen Louime ${ }^{1, *}$, David Hernandez-Martich ${ }^{2} \&$ Omar Paino Perdomo ${ }^{3}$ \\ ${ }^{1}$ University of Puerto Rico, Av. Ponce de Leon 310 - San Juan, PR 00931, USA \\ ${ }^{2}$ Universidad Autónoma de Santo Domingo, Av. Alma Mater 200 - Santo Domingo, DN \\ 10105, Dominican Republic \\ ${ }^{3}$ Instituto Tecnológico de Santo Domingo, Av. de Los Próceres 49 - Santo Domingo, DN \\ 10602, Dominican Republic \\ *Corresponding author: University of Puerto Rico, Av. Ponce de Leon 310 - San Juan, PR \\ 00931, USA. Tel: 1-787-764-0000. E-mail: Cliford.Louime@upr.edu
}

Received: January 23, 2022 Accepted: February 28, 2022 Published: March 6, 2022

doi:10.5296/ije.v14i1.19496

URL: https://doi.org/10.5296/ije.v14i1.19496

\begin{abstract}
Knowledge is the new wealth! Apple and Google, two of the most valuable companies in the world, are prime examples of this new reality. Driven mostly by novel advances in science and technology, these global brands have significantly changed our way of life. This awareness is now forcing countries around the world to seek new ways to keep up with this ever-evolving economy. These countries also agree to the concept of scientific innovation being synonymous to higher education. Therefore, in order to remain competitive in a globalized market, developing countries in particular are now called upon, to train a new cadre of future workers to a higher standard. Training skilled workers and making them available to the wider economy have become a daunting challenge for the developing world. Case in point, the oldest university in the Americas, Universidad Autónoma de Santo Domingo UASD, just received its first patent in 2020, after more than 500 years of existence. For too long, higher education has been assigned a relatively low priority, as one of the major economic sectors in the Dominican Republic, the tourism and hospitality industry, does not require highly technical trained workers. By any measure, making the leap from teaching to research intensive universities is not a small task for the Dominican government, especially, considering their current situation of chronic underfunding, underpaid faculty, and underdeveloped curricula. With an everincreasing student population, institutions of higher learning in the Dominican Republic can barely maintain their current position, let alone catch up to the MITs and Oxfords of the world, which are constantly raising the stakes. Here we propose a few scenarios that may help academic institutions in the Dominican Republic or the developing world as a whole, increase their potential of promoting growth and economic development in this global economy.
\end{abstract}


Keywords: higher education, developing countries, Dominican Republic, economic development, science and technology, global economy

\section{The Role of Higher Education in a Country's Economic Development}

Higher education and economic development are tightly intertwined. Studies have shown that an advanced degree cannot only promote income growth but also increase relevant skills, while expanding choices, which ultimately enlighten leaders (Burciul, 2018; Perna, 2014; United Nations, 2019). Indeed, higher education is fundamentally important to development, as it promotes income growth. According to the College Payoff, over a lifetime, individuals with a bachelor's degree earn on average $\$ 1$ million more than their non-graduated counterparts (Carnevale, 2000). This goes to show the importance of higher education, which has become an increasingly important determinant of a nation's ranking in the world economy. In the Dominican Republic, a hospitality worker earns on average 6000 - 9000 pesos or $\$ 100$ - $\$ 200$ US dollars monthly, which is less than what a US burger occupying the same position earns in a week (Salary Explorer, 2021). This major discrepancy is reflected not only in their quality of life, but also limits social mobility of the average Dominican.

Income growth has also been associated with new knowledge creation, which is a public good driving economic development (Darvas (World Bank), 2017; United Nations, 2019). These goods strengthen not only civil societies, but also promotes democratic governance by providing a safe space for an open discussion on which values constitute the character of a nation. Other characteristics that have been linked to income growth include productivity, political participation, and entrepreneurial energy (World Bank, 2017). These, however, do not clearly differentiate Americans from Dominicans, as the latter are hardworking individuals and highly active politically. But we all would agree that economic growth provides substantial improvements to people's lives and is a powerful determinant of poverty alleviation. Ultimately, by contributing to growth, higher education leads to better living standards for people at all levels of a society.

A second aspect where higher education can promote economic development in the Dominican Republic is by enlightening its leaders. It is well known that higher education not only provides technical skills but also can expand the breadth of knowledge needed by leaders to effectively address societal and economic issues plaguing their country (Chankseliani, 2021). The people of the Dominican Republic seem to understand this phenomenon as they voted for a new president in 2020. After almost 20 years of being led by the Dominican Liberation Party, the people have decided to go with Luis Abinader of the Modern Revolutionary Party, an economist, technocrat, businessman and US graduate. A lot of hope is placed in this new president to provide leadership capable of confronting the new economic realities of the world (The Economist, 2020).

The third and maybe most relevant aspect, where higher education can promote economic development, is providing to workers increasingly relevant skills. Higher education is absolutely necessary for training scientists, engineers, and others to help invent, adopt, and operate modern technology in all sectors (World Bank, 2021). This issue is so timely as reflected in the current pandemic, where the Dominican Ministry of Public Health only has 4 
trained employees capable of running the PCR machines. Delays in samples processing have exacerbated an already fragile healthcare system incapable of handling more than 50000 COVID-19 cases (MSP, 2020). A well-thought-out higher education system would have inspired locally trained Dominicans to define and address local problems, while making major contributions to vital areas such as public health, climate change and food security.

Higher education is not the silver bullet that is going to propel the Dominican Republic into a bright future. It has to be linked to a broader well-functioning social and political system. The current economic realities of the Dominican Republic will not allow higher education to dominate the policy agenda, as other key sectors such as tourism, security, agriculture, health and transportation have been prioritized in the past. But it will offer options in STEM (Science, Technology, Engineering and Mathematics) that may assist the leaders in addressing current economic and developmental issues from a different and maybe better perspective. As seen around the world, in the likes of Microsoft, Google, Amazon, Facebook, Alibaba etc., the economy is being driven by BIG DATA developed and analyzed by highly educated workers with tertiary degrees (Forbes, 2020). Therefore, higher education should be given a prominent space into the future economic development of the Dominican Republic.

\section{Current Status of Higher Education in the Dominican Republic}

The Dominican Republic has 5 public and 47 private institutions of higher learning, enrolling some 400,000 students. Education is free in the public sector, most notably at the Autonomous University of Santo Domingo (UASD, Universidad Autónoma de Santo Domingo), which boasts 17 Regional University Centers around the country and enrolls 45 percent of the total tertiary student population (https://www.uasd.edu.do/). According to a report (Table 1) from the Department of Higher Education, Science and Technology of the Dominican Republic (Ministerio de Educación Superior, Ciencia y Tecnología - MESCyT - Informe General Sobre Estadísticas de Educación Superior), enrollments have consistently increased over the last 20 years, from a gross enrollment ratio of 10 percent in 2000 to over 30 percent in 2020 (https://mescyt.gob.do/). This is happening in tandem with the shift of the Dominican economy towards service industries.

Almost $95 \%$ of students currently enrolled in tertiary education in the Dominican Republic are enrolled at the undergraduate level, $2 \%$ in graduate school and $3 \%$ in technical school (MESCYT, 2018). With more than 65\%, women make up the majority of these undergraduates. According to the World Bank, undergraduate education in the Dominican Republic predominantly trains students for what is widely considered as "low-skill, administrative and clerical jobs." In reality, the problem in the Dominican educational system begins at the primary and elementary level, characterized by poor quality and low effectiveness, with high dropout rates. These are hard-to-remedy problems, according to the World Bank (World Bank, 2018). The UASD uses an equalization program trying to fill some of these gaps. But this program only reaches $20 \%$ of the newly enrolled students every year. Bear in mind, that UASD enrolled on average 30,000 students annually, a number which surpasses some of the major institutions in the world. Unfortunately, the relatively high tertiary enrollment rate is tempered significantly 
by an average dropout rate of approximately 50 percent (https://www.uasd.edu.do/). Inadequacies of their prior education force students not to complete their education in a timely manner. It takes on average 5-6 years to complete a bachelor's degree, with most never able to complete (MESCYT, 2018). As the World Bank puts it, when it comes to student's enrollment, the higher education system in the Dominican Republic is what you would consider an overachiever, however when it comes to students' retention, the system is greatly underperforming.

Table 1. Enrollment in Higher Education, Population Demographics, Population 18-22 Years Old, and Gross Enrollment Rate, 2012-2017

TABLA 1

MATRICULA EN EDUCACIÓN SUPERIOR, POBLACIÓN DEMOGRÁFICA, POBLACIÓN DE 18-22 ANOS Y TASA BRUTA DE MATRICULA, 2012-2017

\begin{tabular}{|c|c|c|c|c|c|c|c|}
\hline ANO & $\begin{array}{c}\text { CANTIDAD } \\
\text { DEIES }\end{array}$ & TOTAL & VARUACION & $\begin{array}{l}\text { POPL } \\
\text { DEMOO }\end{array}$ & $\begin{array}{l}\text { EION } \\
\text { AFICA }\end{array}$ & $\begin{array}{l}\text { RELACION } \\
\text { PORCENTUAL } \\
\text { POBLACION } \\
\text { 18-22 } \\
\text { POBLACION } \\
\text { TOTAL }\end{array}$ & $\begin{array}{l}\text { TASA BRUTA } \\
\text { DE } \\
\text { MATR'CULA*(\%) }\end{array}$ \\
\hline 2012 & 42 & 445.909 & & $9,680,963$ & 916.961 & 9.47 & 48.63 \\
\hline 2013 & 48 & 426.781 & -19.128 & $9,784,680$ & 920,636 & 9.41 & 46.36 \\
\hline 2014 & 48 & 455,822 & 29.041 & $9.883,486$ & 924,227 & 9.35 & 49.32 \\
\hline 2015 & 49 & 480,103 & 24,281 & $9,980,243$ & 927,787 & 9.30 & 51.75 \\
\hline 2016 & 50 & 505,936 & 25,833 & $10,075,045$ & 928,340 & 9.21 & 54.50 \\
\hline 2017 & 48 & 562,667 & 56,731 & $10,169,172$ & 928,845 & 9.13 & 60.58 \\
\hline
\end{tabular}

Fuentes: a) Depto, de fstadistica del MFSCrT, Informes General sobre fstadisticas de fducacion Superior, 2012, 2013. 2014,2015 y 2016, y recolecciones estadiaticas de las IES 2017. b) Estimaciones y Proyecciones Nacionales de Poblacion 1950-2100, 2014. Oficina Nacional de Estadistica (ONE), actualizado 1 diciembre 2014.

Nota: * Para el cilculo de la tasa bruta de matricula se utilizó el rango de edad 18-22, utlizado por UNESCO (UIS), para la Educación Superior.

\section{GRÁfICO 1}

EOUCACIÓN SUPERIOR: TASA BRUTA DE MATRÍCULA

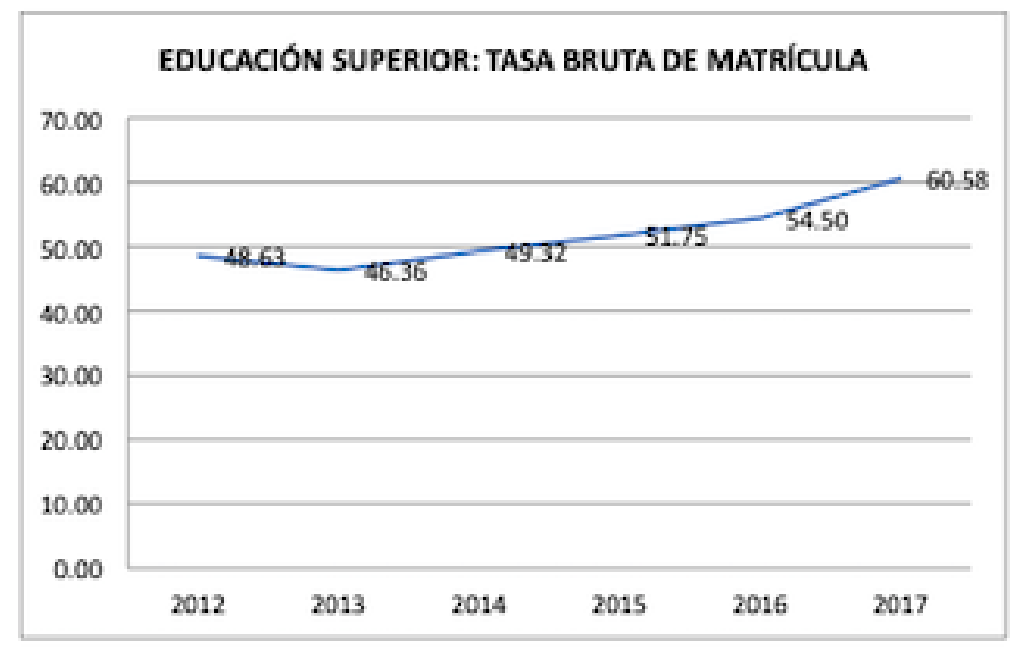

Source: General Report on Higher Education Statistics 2017 and Historical Summary 20052017 (MESCYT, 2017) 
Fuentes: a) Depto. de Estadística del MESCYT. Informes General Sobre Estadísticas de Educación Superior, 2012, 2013-2014, 2015, 2016 y 2017, y recolecciones estadísticas de las IES 2018. b) Estimaciones y Proyecciones Nacionales de Población 1950-2100, 2014. Oficina Nacional de Estadística (ONE), actualizada 1 diciembre 2014.

In light of these findings, the Government of the Dominican Republic has set out to place higher priority on secondary and postsecondary education (MESCYT, 2018). These reforms have included not only infrastructure building, but also effective and credentialed vocational education and training. The Department of Education's ten-year strategic plan also includes a $50 \%$ increase in participation of young adults in higher education. Such a plan has translated into an enrollment of almost $700 \mathrm{~K}$ in the educational system, a doubling of the current enrollment rate (MESCYT, 2018). If this increase could be coupled with a $20 \%$ reduction in attrition, the country can see the number of its graduates more than double in a decade. Of course, all these reforms require new physical infrastructure to accommodate this onslaught of newly admitted students, including qualified professors.

In order to meet these requirements, the Department of Higher Education, Science and Technology (MESCYT), who runs the program of revamping higher education in the country, has decided to look beyond its borders by awarding almost 10,000 scholarships to Dominican students to get a graduate degree at a prestigious university abroad (MESCYT, 2018). These awards were made only in key areas for national development and competitiveness, such as STEM (Science, Technology, Engineering, and Mathematics). On average 300 students are being sent abroad for 1-2-year masters and 3-4 years doctorate programs, as there are no institutions in the country that offer $\mathrm{PhD}$ degrees. Unfortunately, due a language barrier and not meeting some of the American university's admission requirements, most of the participants chose to go to Spanish speaking countries, such as Spain instead of the US. Almost half of the ones who joined American universities were admitted to Nova Southeastern University, a TIER 2 private institution in South Florida, with a heavy focus on healthcare sciences (MESCYT, 2018). Finally, as a complementary approach, the Department of Higher Education has also been recruiting foreign faculty to supervise doctorate students locally.

All these initiatives are slowly paying off, as the number of students at the graduate level has increased some 40 percent to over 400 in the country (MESCYT, 2018). Dominican students heading to the US for graduate schools have also been consistently increasing over the past few years. This is due partly to several Intensive English Programs initiated by the Department of Higher Education. Finally, to close that gap, several institutions in the DR have entered into bilateral agreement with institutions abroad, mostly in Spain to offer dual-degree programs at the graduate level to Dominican students. Although the number of international students in the DR remains low (around 2\%), the rate of Dominicans heading abroad to complete graduate degrees have consistently been increasing. This should lead the country toward a future where science and technology will be called upon to play a larger role in society, democracy, and economic development.

\subsection{Challenges of Higher Education in the Dominican Republic}

Over the past few decades, higher education in the Dominican Republic has faced a whole host 
of challenges. By focusing on primary education for girls, the government has turned his back on secondary and tertiary education, leading to the system being totally underfunded (World Bank, 2021). Even donors have neglected higher education, and as a result the country has experienced a deteriorating education system with low quality and limited access (United Nations, 2021). In addition, the system is extremely politicized and remains poorly regulated. There are even reported cases of corruption (https://elnacional.com.do/maestros-denunciancorrupcion-se-traga-recursos-del-4-para-la-educacion/). The issue of underfunding is a chronic problem that is hard to address in the face of the number of competing demands for public funding. A recent report from the United Nations pointed to several issues that need to be addressed, such as the quality of the teaching faculty, who are poorly rewarded and therefore lack the necessary motivation to engage their students, including a curriculum that is underdeveloped (United Nations, 2018). All these have led to a noticeably high level of attrition, and poor preparation at the elementary level.

\subsection{Online Education}

The Dominican Republic is an upper middle income less-developed country with a GNI per capita over $\$ 6000$ (World Bank, 2018). Yet over 30\% of the population falls below the national absolute poverty line, and only $12.4 \%$ of the population aged 25 and older have completed even short-cycle tertiary education, with a current $29 \%$ schooling participation rate of 18-24-yearold. CITE The country is still in an early stage of distance learning expansion, offering the chance for a mutual interchange of ideas. But Internet connectivity is rising-with a $56 \%$ penetration rate in the Dominican Republic, for instance (Miniwatts Marketing Group, 2018) to allow for expansion of online coursework. Yet much of this is based in expanding mobile phone network coverage which does not always translate into online educational opportunities. Home computers (with Internet availability) remains a crucial indicator. Residential internet service provision also remains highly skewed; 2015 household survey data suggests only $28 \%$ of households have computer access while only 21.2\% subscribe to Internet service, particularly in the cities of Santo Domingo and Santiago de los Caballeros (Mazara, 2017). These numbers have risen to $34.1 \%$ and $28.3 \%$ in 2018 , but remain below the regional average (ITU, 2018). (Table 1)

The Dominican government has sought to modernize university education carefully through the creation of the National System of Education, Science and Technology (SEESCYT) and specific plans calling for diversified modes of study (OECD, 2015). None of the country's universities have worked under the Laureate Education system but have relied upon a mix of US and domestically created content for distance education courses. Some courses include international MOOC content but within the virtual classroom (learning management system) of the campus. Since 2006 SEESCYT authored the "Rules for Higher Education Distance Education Institutions and Programs" 09-206 to guide national university transitions (SEESCYT, 2006). Various articles emphasize quality assurance of content and periodic evaluation of distance education programs, as well as the definition of content across synchronous and asynchronous formats. Much Dominican distance higher education incorporates a concept of virtual coursework as that which has a separation of student-professor, independent learning, indirect communication, and university provision of learning materials 
(Peralta, 2009).

Distance education began with "Escuelas Radiofónicas de Radio Santa Maria" for rural literacy and has spread to some K-12 math programs. The earliest university endeavor, UAPA (Open University for Adults), was founded in 1995 with a specific distance education mission linked to competency-based achievement. Next, UNICARIBE and smaller universities joined this open distance/virtual model; UNICARIBE started in 1995 as an open distance university focused on the blended/hybrid (semi-presencial) model. By 2009 classes given in these formats (hybrid or virtual) represented about $7.5 \%$ of the national matriculated study body (Aybar, 2010). During this period the use of virtual curriculum was highly regulated by the Ministry of Higher Education (MESCYT) under 09-206.

Today 5-6 of the private large city universities (including INTEC, UNAPEC, UNIBE, PUCMM, UCSD, UTESA and others) offer some form of hybrid online coursework, with $100 \%$ online material centered in master's degrees. The public university (UASD) has an e-Learning program with student choice of modes (online, in-person) across hundreds of classes. Teacher training and certification for online pedagogy remains an outstanding issue, particularly since the large majority of university professors work part-time contracted by hour (Peralta, 2009). UNIBE (Universidad Iberoamericana) a small private higher education institution with 5,0006,000 students offers some of the general education coursework in blended format through the Moodle Learning Management system. Blackboard was adopted in 2019 with only 1\% of matriculated students taking blended courses (Arbaugh, 2009).

However, under the COVID-19 crisis initiating in March 2020, universities in the Dominican Republic were forced to make strong changes towards online learning. Most HEIs rapidly moved to have all classes in the spring trimester become remote learning. Summer 2020 and Fall 2020 classes were also offered in the fully online modality. While assessment of student learning under these changes is not yet possible, it is worth noting that some HEIs sought to become affiliated with Quality Matters in the summer of 2020. As a worldwide organization, Quality Matters seeks to provide guidelines for effective online learning course design. It has designed rubrics for ideal course website design and offers a peer-review process of courses and programs interested in certification under these guidelines.

\subsection{Science and Technology in the Dominican Republic}

When it comes to advances in Sciences and Technology, the gap between the West and the Dominican Republic (even the entire southern hemisphere), is not only enormous but it is constantly widening. Although they are conscious that these scientific and technological developments are changing their world at a rapid pace, not seen before in human history, they are still having a hard time to keep up with these changes. To their defense, even institutions in developed countries are struggling to keep up with the changing pace, particularly in the areas of computer sciences (Artificial intelligence and robotics; Big data analytics; Computerassisted education; Bioinformatics; Cyber security...etc.). Advances in Communications have also revolutionized the world, with companies like Apple coming up with a new iPhone every 6 month. Therefore, one would understand the types of challenges that the Dominican Republic is facing, or whether these advances do not represent an opportunity to propel the country 
forward. Either way, the Dominican Government including all stakeholders should have all hands-on deck and make higher education or education at all levels, their highest priorities. As stated earlier, higher education is the only way toward a future of strong science and technology.

The challenges faced by the world today, whether medical, environmental, or economic, call for a highly skilled workforce. And only higher education can help us meet this demand. However, when we consider the following North-South discrepancies, we have reasons to be concerned about the future of the Dominican Republic:

a) Europe dedicates more than 2\% of its GDP to research and development, while the Dominican Republic spends less than 0.5\% (UNESCO, 2018).

b) Countries like France, Spain and Germany have per capita 10 times more scientists than the Dominican Republic.

c) Science degree programs at the tertiary level attract way more students in Europe than in the Dominican Republic, where graduate programs are being slashed all over the country.

d) Almost $90 \%$ of all scientific publications come from the US, Western Europe, and Australia.

e) The North also accounts for more than $97 \%$ of all patented technologies in the world. The DR while claiming to have the oldest university in the Americas, can barely boast 4 patents with limited to no commercial value.

Science discoveries have been driving economic growth around the globe. These advances have also positively impacted the livelihood of millions of people. Here are a few prominent examples that have elevated living standards the world over:

a) High yielding varieties of rice

b) Plastic (cheap and durable)

c) Antibiotics

d) Electricity

e) Oral Contraceptives

In all of these advances, higher education has been fundamental (Belfield, 2018).

In addition, higher education allows countries to not only implement existing technologies, but more importantly generate new knowledge adaptable to their own reality. To get to that point, the Dominican government needs to put a system in place that provide:

a) access to high quality laboratory facilities, equipment, and supplies

b) highly trained teachers

c) sufficient motivated and well-prepared students

d) international scientific collaborations 
e) access to up-to-date knowledge

All these can only be accomplished if the government prioritizes education and recognizes its worldwide benefits. Other initiatives should include financing the development and maintenance of scientific capacity, including investments in research and raising awareness among the general public about the importance of scientific inquiry. These efforts will require:

a) Physical and technical resources

b) Human resources

c) Local, regional, and international cooperation

d) Strategies for scientific development; and

e) University-Industry cooperation.

\section{The Way Forward for the Dominican Republic}

Most scholars agree that higher education is fundamental for economic development. The world economy relies heavily on knowledge and skills generation. Therefore, it is no longer a luxury to invest in higher education, as its benefits are constantly rising. Countries who failed to follow that path will be left behind, and this failure can be costly. The wealth of a nation is no longer measured by its manufacturing power, but by its human capital investment (Lange, 2018). The latter is believed to be three times more valuable than physical capital. Consequently, most nations are called upon to look at higher education as a major political priority, where advanced skills and knowledge are generated at the tertiary level. And this process should be a lifelong endeavor as the world economy is rapidly changing.

In order to keep up with this constantly changing world, leaders must adopt a different approach to education. This should be comprehensive, meaning at all levels, from kindergarten to tertiary education, and also more balanced. As shown in the past, focusing on primary education alone has left a lot of nations, including the Dominican Republic, unprepared to address tomorrow's issues. To fill that gap, the DR government in consultation with the civil society and international organizations, should immediately address the following:

a) How can higher education enhance economic and social development?

b) What are the major obstacles faced by higher education?

c) What solutions are we proposing to overcome these shortcomings?

\section{The Role of Higher Education in building a Democratic Society in the Dominican Republic}

In the Dominican Republic, a strong and forward-looking higher education system will benefit tremendously the larger society, as it will create the foundations for an open and more 
meritocratic society. Values derived from a solid higher education system tend to be more inclusive than other venues of society, including churches and families. As being practiced in democratic spaces around the world, open debate and argumentative reason are fruits of a flourishing higher education system. These types of social interactions promote self-reliance of each of its individual members, while encouraging them to embrace non-discriminative values or reject discrimination based on gender, religion, ethnicity, and sexual orientation. In all, institutions of higher learning are models, and an impetus to create a more modern and inclusive society. This will ultimately lead to a more pluralistic and accountable democracy (Loannis, 2017).

Universities and colleges are best suited to advance debates and research on the type of political democracy leaders and stakeholders agree to adopt. That's where the Social Sciences come in. However, Humanities also have a significant role to play in the process, as they are the key players to address issues such as ethics and morals that define a society. Combined with other disciplines, such as History, these studies should bring a lot of objectivity while testing ideas against observation (Thomas, 2017).

Democracy requires enlightened citizens, which higher education helps promote by instilling in them specific norms and attitudes. These values, such as pluralism, tolerance, merit, and reasoned argument are crucial not only for the development of a democratic society, but also for the educational process (Johnson, 2019). And they are passed onto the next citizen through business practices, teaching and other types of interactions. Institutions of higher learning ensure that society keeps some sort of a shared memory. For example, teaching history to students is in a way of forging their future, by reminding them how they got where they are now.

Finally, higher education has always been home for nonpartisan discourse, including tolerance and truth. These public expectations are necessary for a flourishing democratic society. Although, institutions of higher learning always have had a tough time reflecting these sentiments or distancing themselves completely from the political climate of their surroundings; they have always represented an ideal to be inspired by. Consequently, these institutions have always been the first targets of strong men around the world (Glaeser, 2007).

\section{Some Practical Solutions to be Implemented in the Dominican Republic}

Globalization and curricular competence have generated transformations in higher education, focused on the following concepts: competitiveness, market forces, clients, science-technology parks, industrial innovation, transnational education, regional development, among others. In this process of transformation, higher education in the Dominican Republic presents a series of challenges that must be specified within the scheme of divergences and convergences in learning structures to be in tune with the Bologna Process, in which other countries are advancing in the region. The higher education system in the Dominican Republic has experienced enormous growth in terms of enrollment, the same process of massification, added to the increase in new higher education centers in the country, most of them concentrated in the 
capital city. This creation of private universities that are called "garage universities", due to their weak academic quality, schedules, modality and due to the physical infrastructure conditions. Not a single university in the Dominican Republic appears in the 2021 World Ranking of universities including in the publication of scientific articles (https:/www.topuniversities.com/university-rankings/world-university-rankings/2021). It is true that gradually the conditions of change in higher education in the Dominican Republic have undergone processes that lead to transformation, expansion, and diversification, through multiple actions, projects, and educational programs. However, most of these rest on political interest, not on country need, and are as a trend and not as a finished model which should focus on a) Promote the mobility of students, teachers, researchers with due recognition or validation of the study period; b) Encourage the articulation between training and employment; c) Master's and doctoral programs. These three approaches are critical. Student and teacher mobility are minimal or null. Many students enter a career when the supply of demand is not there, and the graduate programs are very small or very expensive. Based on this process, it is necessary to carry out transformations in the educational system in areas such as degrees, length of careers, structuring of periods, thematic contents of the programs and standardize the credit system; in order to create a convergence for the purposes of obtaining a job, continuing their professional studies in another country in the region, professional mobility, cooperation with universities in the region and Europe and responding to the change that is sought in a society of the knowledge-learning.

\subsection{Financing for Education}

The development of basic sciences focuses on raising and strengthening the socio-economic development in developing countries through the research process. Currently the Dominican Republic is framed in the context of developing countries from a macrosocial and macroeconomic approach. The Dominican Republic, together with the different higher education institutions, have an extremely important role in instruction and training to generate knowledge, disseminate it and make it socially accepted. In order to achieve the strategic objectives for economic-social development, the contributions of science, technology and innovation are necessary, which are involved transversally with higher education, in order to respond and satisfy national demands.

Public higher educational development priorities should focus on:

1- Government support for financial allocations.

2- Management of financial resources.

3- Continuous training of professionals.

4- Support that society offers to Science, Technology, and Innovation (STI).

5- Research and development.

The aforementioned priorities constitute the fundamental actions necessary to be implemented by the Dominican Government. It should be noted that the socio-economic development achieved in the country in the last decade is basically reflected in infrastructure (roads, 
buildings, tourist areas, etc.). Unfortunately, scientific development focused on recruitment, incentive for researchers, research assistants, professors and students, and financial support have been very gradual.

The globalization process brought with it the industrialization of science. The Dominican Republic should focus on establishing an alliance with industry as a generator of science, increasingly directed or oriented towards academic activity and science becomes an integral part of the industrial sector. Currently, there is a trend to homogenize Science, Technology, and Innovation policies according to the main scientific policy advisory organizations, such as UNESCO and the Organization for Economic Cooperation and Development (OECD). The scientific policies in the country must adjust to the linear models of innovation (disciplinary) to solve problems of the academic community and non-linear (transdisciplinary) associated with the context of economic-social application.

Based on these models, an initial solution would be the adoption of a non-linear innovation model with the current adaptations demanded by each socio-economic and university context according to the country's need. This will help break the monopolization of knowledge by of some decentralized institutions or groups of the state and research institutes of the universities. That will also create a dynamic and interactive model between higher education and collective managers: universities, institutions, companies, and other organizations such as NGOs.

There is currently no productive cognitive symbiosis between science, innovation, and technology in the Dominican Republic. Science is restricted to universities, centers, laboratories, research groups and public or private institutions, and on the other hand technology and innovation is the company, especially multinationals based in the country or other organizations dedicated to production of goods and services.

The Dominican State must further stimulate the dynamism of innovation and development and financial support (subsidies, tax exemptions, support for infrastructure, teacher mobility, job recognition, among other alternatives). Unfortunately, this is not the panorama that is observed in the country, where a range of situations are presented that include priority problems of different types: food, citizen security, housing, health, unemployment, infrastructure, tourism, mining, basic education, etc., where higher education and STI are not necessarily on the priority agenda.

The Ministry of Higher Education, Science and Technology (MESCyT) is the institution that has institutionalized science. It has framed a vision of scientific development with the creation of the National Fund for Innovation and Scientific and Technological Development (FONDOCyT). The MESCyT has been in charge of the elaboration and implementation of policies that favor the generation of science. In addition, the professionalization of those who carry out research has been established with the creation of the National Race of Researchers in Science, Technology, and Innovation.

These three steps summarize the titanic efforts that have been made to develop STI in the country with a view to conceiving a social, pluralistic, political, economic, sustainable, environmental development, etc. It is necessary to stimulate and promote collaboration, 
cooperation, and assistance between national, regional, and international institutions in order to develop STI. The capacity for innovation and the creation of new technologies are closely related to human capital, the main sources of financing; therefore, a short-term and immediate strategic intervention of the government is needed to achieve the development of STI.

One of the purposes of FONDOCyT is to finance science, technology, and innovation activities, which include investment in research and technological development, which in turn includes resources for basic, applied, and experimental research and for the formation of highly qualified human capital. These actions have been made evident in the approved programs and projects on agriculture and livestock, health, in topics such as the generation of germplasm banks, research for new species and varieties, molecular analyzes, biological collections, generation of new applied knowledge evidenced through publications. But more efforts are still needed to create the culture of inquiry.

The new challenge is the creation of knowledge through research, its distribution through teaching, its applications, generation of patents, publications, discoveries, solutions to environmental, health and technology transfer problems. This challenge will be possible with the realization of a single long-term strategy for the formulation of projects within the framework of a common cooperation between multilateral organizations and inter university networks. This may be possible if the traditional criteria of isolated work, professional jealousy, availability, and access to scientific information are overcome and if strategies, programs, agreements, joint projects, and financial partnership are proposed, with the aim of making cooperation a tool that goes beyond one-sided visions to create a strategic and functional path.

\subsection{Professional Training and Teaching Strategies}

Teaching techniques in public higher education in the Dominican Republic are characterized as being outdated. They are based on repetitive and memorized learning, without any reasoning. Many of the teachers do not master ICT (Information and Communication Technologies) for teaching. They use outdated teaching methods, such as: reading cards, copying notes on a blackboard, outdated manuals, without assigning textbooks as supplementary material. A photocopy assignment system is practically used, which students must go to the assigned copy center to look for class materials. Many students have the financial constraint to acquire a textbook for the teaching process. In addition, the teaching body is characterized by having a very small number with a postgraduate level education. This situation is a limitation for the transfer of knowledge imparted to students and restricts the ability of students to access updated knowledge and generate new ideas. An educational revolution is needed in the Dominican Republic, which is focused on the vision of globalization, of the latest advances in science, that is creative, active, and pluralistic.

\section{Salary Remuneration}

Incentive pyramids are ill-conceived. Salaries in the Dominican educational system are governed by teaching load systems, the higher the teaching load (40 hours per week) the higher the remuneration. This teaching load makes the research process difficult, although many 
professors have no interest in exercising the research role. It is very common for a single instructor to teach multiple subjects that are not related within the same discipline. There is no reward for good professional performance, and salary disparities make it difficult to attract talented people, and bureaucratic procedures for hiring and external and internal competition hinder intellectual growth. Practically the Dominican university professor has a modus vivendis of moonlighting and excessive absenteeism. These two factors do not encourage architectural design to build an atmosphere that encourages learning and inquiry. In addition, some professors lack a physical space or office to offer personalized attention to undergraduate students.

\section{Political Activities in Public Higher Education}

University bureaucracy and corruption are part of an imposed culture, which affects the selection and treatment of students and professors in the Dominican Republic. Added to this is favoritism, cronyism, and politics. Based on politics, a politicized academic atmosphere is alive, where power, more than merit, weighs more in making important decisions and a lot of productive time is invested in establishing political alliances and strategies to take command or exercise control. Political activity in the academic environment should help address injustices and promote democracy. Due to the politicized system, research, teaching, learning, extension is extremely difficult when a few members of the faculty, students and student groups take positions as combative agents of rival political factions or the government of the day.

\section{College Life}

The public university in the Dominican Republic has an excessive student population of over 235 thousand students. For those who do not have aptitude tests, entrance exams, inductions, etc. due to their socioeconomic situation, the educational process can be very difficult for them. These students lack adequate libraries, laboratories, recreational green areas, adequate bathrooms, study in extremely overcrowded classrooms, while few services are available for them. The one public university with all its campuses depend on the central government for its financial resources. Practically a high percent of its budget is dedicated to personnel costs, leaving few resources for the maintenance of infrastructure, libraries, equipment or supplies, acquisition of laboratory instruments; all key ingredients in maintaining a research establishment. Facilities are built that run out of funds for operation and maintenance, due to poorly coordinated capital and operating budgets. In addition, most buildings are in a state of disrepair, inadequate libraries without an information system, exclusive computer laboratories, obsolete laboratory instruments, without emergency exits and scientific equipment that cannot be used due to lack of supplies and spare parts.

Since the changes that emerged in the traditional university in the 18th century, there has been an emergence of the three new university prototypes: professionalizing and expert French (Napoleonic), based on the fact that research is carried out mainly ex situ of the university; German (integrative, fusional and researcher), based on humanistic and philanthropic training; 
and the North American (scientific and technological university). Of these three models, in higher public education, these models are not synchronized in the Dominican Republic, nor are criteria unified in all higher education institutions, due to the socio-economic systems of the student population. And university professors are very complex from an anthropological and social point of view.

In the Dominican Republic, it is very rare to locate universities that dedicate a large part of their financial resources to research projects, except for some whose amounts do not exceed 18 thousand dollars per project; in addition, to the training of instructors, researchers, and students. Many focus on receiving financial resources, which allow them to ensure payroll, cleaning personnel, electricity services, water, garbage, among others. The Dominican government needs to create the necessary tools that allow the formulation of programs and projects with a common language, bringing new actors closer to the concepts of: a) State and governmental decisions focused on educational, scientific, technological, training and financial policies; $b$ ) Economic-productive sectors interested in acquiring scientific-technological results; c) Creation of networks or institutional groups of instruction and knowledge; d) A human heritage, without professional jealousy in the university education system; d) Innovation activities; e) Scientific and technological services.

Table 2. Quality Assessment Survey of Higher Education in the Dominican Republic

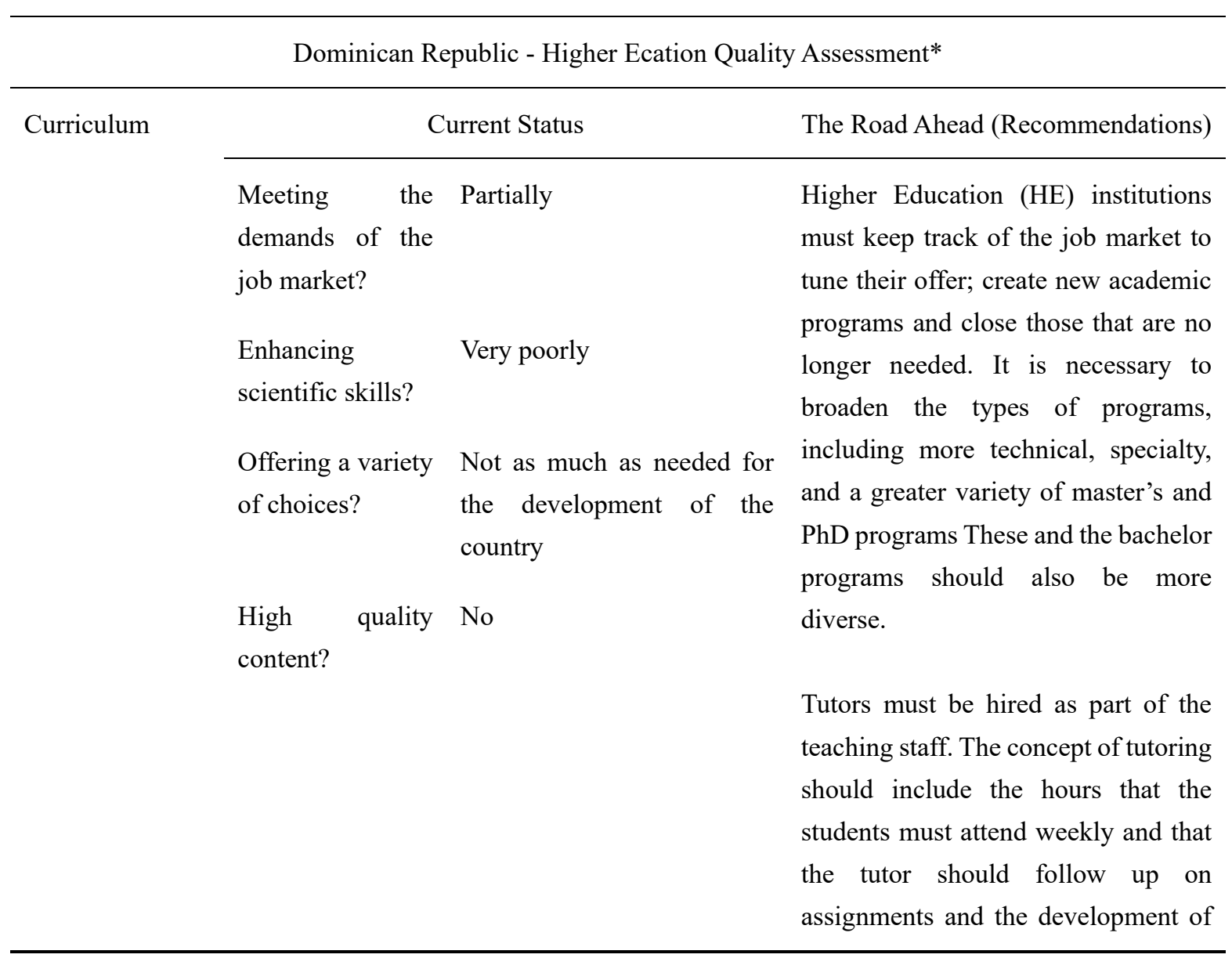


the student in his/her degree program.

More attention should be put on the development of scientific skills and giving more opportunities to the students to get involved in scientific research projects.

To improve the quality of the contents, HE institutions should start by planning better their programs, choosing better their faculty, paying better their faculty, giving them opportunities for professional development so they can acquire the skills needed to teach (pedagogy and TICS), improve students recruitment, and advise them in the selection of their major, etc. All the programs should lean more towards the development of competencies.

One of the problems of the HE in DR is that the entire pre-university education is poor. So, no matter how much we make improvements in the HE system, the results that we aim to attain will not be achieved. Ironically, one of the culprits of this problem is the HE system itself because it is the responsibility to form the teachers for Basic and High School Education.

In a survey conducted by MESCYT and MINERD, they found out that education programs in DR $\mathrm{HE}$ institutions have a very low percentage of content of the subject that the future teachers were intended to teach; and the quality of the courses on pedagogy and other subjects to develop the teaching skills was low. To change this situation, the DR 
Government came up with the Norm 09-15 and made sure that the universities opened educational programs with a higher content on the discipline to be taught and based on the development of competencies.

Another action that must be taken to improve the quality of the content is to increase the number of professors with a doctoral degree (From recognized universities). Also, keep the maximum number of students in a class adequate to the subject and conditions. Most people do not believe in ONE standard number. For instance, large groups are possible for theoretical courses in large comfortable rooms with conditions for the professor to speak and students to hear without much effort, and teaching assistants to help in the classroom and evaluate student assignments.

Performance? In a scale of 1 to 5 , probably $30 \%$ of the faculties have a performance rated between 4 and $5 ; 50 \%$ between 2 and 3 ; and $20 \%$ have a performance rating of 1 .

Academically qualified?

Dedication?

full-time faculty?
More than $60 \%$ have no training on pedagogy.

More than $80 \%$ have no skills to teach online.

About $30 \%$ do not have adequate knowledge of the subject matter they are supposed to teach.

More than $60 \%$ of the faculties work in two and more universities and/or
In addition to better pay and opportunities to improve teaching skills and being updated in their field, the institutions should have a better system to supervise and to provide support and assistance to their staff. At the same time, the staff should feel that they are treated with dignity.

An effort should be made to increase in the next five years the relative proportions of full-time professors to $60 \%+$ and to $80 \%+$ in the next ten years. 
have another type of job, and the remaining $30 \%+$ are not necessarily hired as full-time faculty.

Incentive? Is The salary for faculties is not salary adequate? adequate, and very often they feel insecure about job security, tenure, or permanence at the job.

It is unfortunate that the incentive to teach in most cases is only the opportunity to make some money without caring to do a good job. Also unfortunate is that it is an incentive that the institutions do not push for a better performance because they do not pay well.

Very often the main incentive is to have the opportunity to work in their vocation.

Infrastructure Facilities

adequate

teaching

research?
In most cases they are not. for Many classrooms are too and small for the number of students, are not clean, lack electricity and adequate light and air flow, have a very high temperature, and are exposed to a lot of noise (either from employees and students or from the neighborhood where the institution is located). They do not have technology to support teaching.

Quite often, the research facilities are also too small, dirty, with bad lighting, air flow, water supply and
Transform the classrooms to a more modern style. Include technological services. Consider transforming permanent courses to be taught virtually in the right way (not what we have to do now because of the emergency). To invest in the development of diverse and adequate sport facilities.

To make sure they have a student clinic that gives services during the whole time the university is offering classes.

We should have a place to sell healthy food services to reduce the risk of students, professors and employees 
Modern

classrooms?

Sport facilities?

\section{Students Clinic}

Career Prospects Need of the labor market?

Employment upon graduation?

Links with businesses?

Exchange

Programs? temperature control, with poor electricity supply, and noisy. Many are not built or conditioned for research.

Probably $20 \%$

Students' clinic and sport facilities are infrastructures that most universities have just to comply with MESCYT regulations.

In some universities, the sport facilities are not diverse, too small and/or are placed in inadequate location.

Only a few universities take into consideration the labor market when they open (or close) new academic programs. By the same token, most teaching is completely divorced from the reality the graduates will have to face.

Some universities care to help their graduates to get a job.

Several universities have links with business for internships and job placement, but it should and should be better.

Dominican universities have not embraced the exchange program in a way that they could benefit fully from it. getting sick because there is not such service at the university, and they must go to the neighborhood to buy food... (I would also add a bookstore).

Outsourcing could be a choice for the last three types of service.

To establish links with organizations to develop a strong formal system that ensures job placement services for the students. This should include a career fair at least once a year.

To make the exchange program an essential part of the academic system, providing the conditions for Dominican students to go abroad and for foreign students to come to DR. Also, to consider a student exchange program among Dominican universities.

The universities should establish a clear and strong policy to put in place communication skills (written and oral) as a transversal competency that must be developed in every course and activity. 
First, there is not a formal system to provide some support for Dominican students to go to foreign universities. There is no student exchange program among Dominican universities. There are not adequate conditions to receive foreign students in an exchange program.

Communications and linguistic skills?

Career fair?

$\begin{array}{rr}\text { Library Services } & \text { Electronic } \\ & \text { resources? }\end{array}$

$\begin{array}{ll}\text { Library Services } & \text { Electronic } \\ & \text { resources? }\end{array}$

Sufficient space? Most university libraries do

Our universities have neglected these important skills for a professional and for the population in general. The general ability to communicate in the native tongue, either in writing or speaking is extremely poor. We are improving our communication skills in English.

The culture of having career fairs is very well rooted in some private Dominican universities. (n)

library.
Electronic resources are
insufficient.

Subscriptions? not have enough space.

Only a few university libraries have adequate services. None of them can be considered a first-class library. insufficient.

A small number of subscriptions to periodic professional and scientific publications to allow a
As they have done for English, they should also improve the development of communication skills for other languages like French or Haitian creole given that we must communicate with our neighbor country and depend highly on tourism.
The library concept must change in all DR universities. More services should be provided, like space to study (alone or in group) and to do research, more e-books and electronic services, more subscriptions to journals, more copies of textbooks for all the courses taught at the university (the library should keep a continuous communication with the teaching units to keep this updated, and with the research unit to satisfy the demands of the researchers).

Their environment should be well 
decent research program.

Process?

Administrative

Supplies

and For research it is not unless

Services

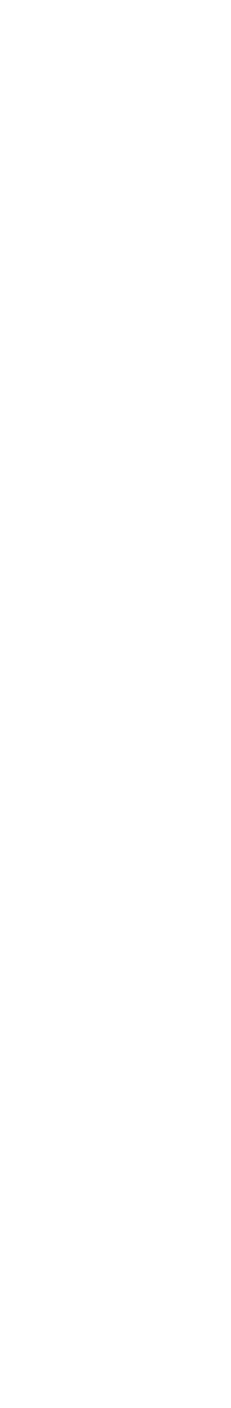

E-Services

IT infrastructure? Poor

Website User- Not at all.

friendly?

Social Network? Poor - only a few universities have intranet.

supplies for teaching, they resources are basic.

The most serious problems that slow down the completion of research projects are the cumbersome processes in the legal consulting, purchasing and auditing offices.

Tech Support? Poor

Clear Guidelines? The guidelines are not in ink, and therefore, they are labile and confused.

Prompt Services? Never
Borrowing It's complicated.

organized, have good lights, adequate temperature, clean spaces including the bathrooms, zero noise.

The purchase and supply units must have adequate employees and written guidelines that they must follow and should be known to all research professors. Those guidelines must include the process with DR Customs when anything will be imported to the country.

The guidelines must also have timelines for the processes.

are limited. Instructional I have similar recommendations for the processes in the legal consulting, accounting, and auditing units. supply, accounting, and

The universities should speed their processes to make sure that they provide assistance and answer requests from their students, professors, and the community. To do this, they should invest in 
The internal communication would be greatly improved with an efficient intranet. This is particularly true in large institutions.

*Assessment conducted, evaluated and written by DR University Professors and Administrators with decades of experience in DR Educational system and across various public and private institutions

\section{Conclusion}

When it comes to the future of higher education in the Dominican Republic, a new vision of what higher education can achieve is required. First, funding, a mechanism which provides increased and consistent financial support for education, has to be elaborated between private partners, international organizations, and the government. Second, resources, teaching facilities with access to new technologies, has to be constructed or renovated to make more effective use of the existing human capital, such as connecting them to the global intellectual community. Third, Curriculum, taught subject matters have to keep up with the changing times and economy, by focusing on skills development that can be further developed as the work environment changes. Fourth, governance, a set of rules has to be put in place and followed on how to manage limited resources effectively. Other recommendations on how to improve the educational system of the country are highlighted above in Table 2, as a result of a survey conducted among universities administrators, professors, staff, and students in the Dominican Republic.

Clearly, higher education institutions in the Dominican Republic need to redefine their mission and adopt well-designed academic programs. To guarantee future success, however, it is vital for them to hire world-class professors, better prepare their students at the primary and elementary level, and provide adequate resources to faculty, students, and staff. Unfortunately, most institutions of higher learning in the Dominican Republic reflect severe deficiencies in all three areas. Over the years, only a couple of institutions have been able to perform consistently at a high level or keep an acceptable standard. For example, The Universidad Autónoma de Santo Domingo, proudly considered as the first University in Latin America, only boasts a meager $10 \%$ of its faculty with graduate level training, some with not even full-time commitment to the university. This results in the inability of the country's elite scientists to 
pursue research and to keep up with the latest in their field. It is a sad fact that higher education in the Dominican Republic is placing tremendous pressure on public budgets. Unfortunately, when universities are not capable of shining and serving as a reference for the remaining of the educational system, the entire country finds itself in a very peculiar position to define international issues impacting them, such as the current corona pandemic and the concomitant economic crisis.

Most scholars agree that in order for the Dominican Republic to play a role in this changing economy, a more creative and flexible approach to education is on the order. There is a serious need for a more enlightened process of learning, one that focuses on active intellectual participation, instead of constantly absorbing facts from textbooks. Improving the quality of education in the Dominican Republic depends also heavily on implementing a culture of independent scholarship, as academic freedom is a foreign concept on most Dominican campuses. Indeed, the politicization of these settings favors a top-down approach on important academic decisions, while hindering exploration of new ways to do things. This culture makes research and training extremely difficult on campuses across the country.

In all, the vision for the future of education in the Dominican Republic should be combined with better planning and higher standards of management. The strengths of all players, both in public and private sector, must be used, with the international community providing strong and coordinated support and leadership in this critical area. Urgent actions to expand the quantity and improve the quality of higher education in the Dominican Republic should be a top development priority. The Dominican government needs to: a) increase the numbers of students with specialized skills; b) train students in general education that encourages flexibility and innovation, thus allowing the continual renewal of economic and social structures relevant to a fast-changing world; c) teach students not just what is currently known, but also how to keep their knowledge up to date, so that they will be able to refresh their skills as the economic environment changes; and d) increase the amount and quality of in-country research, thus allowing the country to select, absorb, and create new knowledge more efficiently and rapidly than it currently does. In all, the Dominican Republic needs to train specialists, which are in increasingly high demand in all sectors of the world economy. The educational system has to become more innovative and flexible to keep up with this fast-changing world. Teachers have the responsibility to provide their students with updated skill sets, that can be refreshed as the world economy mutates. This can be accomplished by increasing relevant in-country research and providing opportunities that limit the brain-drain, as one-third of Dominicans studying abroad do not return home upon graduation.

\section{Acknowledgments}

This publication is the result of an international Fellowship awarded to two American Fulbright Scholars, Professors and US Citizens ambassadors (Dr. Clifford J. Louime and Dr. Denise M. Stanley) by the US State Department to teach and conduct research in the Dominican Republic in 2020. The two Dominican professors and co-authors on this manuscript, Dr. David Hernandez-Martich and Dr. Omar Paino Perdomo, respectively served as host and collaborator 
during the Fulbright grant period.

\section{References}

Allen, I., \& Seaman, J. (2013). Changing course: Ten years of tracking online education in the United States. Needham, MA: Sloan-C.

Alten, D., Phielix, C., Janssen, J., \& Kester, L. (2019). Effects of Flipping the Classroom on Learning Outcomes and Satisfaction: A Meta-Analysis. Educational Research Review, 28, 1-18. https://doi.org/10.1016/j.edurev.2019.05.003

Arbaugh, J., Godfrey, M., Johnson, M., Pollack, B., Niendorft, B., \& Wresch, W. (2009). Research in online and blended learning in the business disciplines: Key findings and possible future directions. Internet and Higher Education, 12, 71-87. https://doi.org/10.1016/j.iheduc.2009.06.006

Aybar, A. (2010). UNICARIBE: un modelo pertinente de educación superior a distancia. In Rama, C., \& Pardo, J. (Eds.), La educación superior a distancia: Miradas diversas desde Iberoamérica. Santo Domingo: Ediciones Unicaribe.

Belfield, C., \& Laura, V. D. E. (2018). The impact of higher education on the living standards of female graduates. IFS Working Papers W18/25, Institute for Fiscal Studies.

Beaver, J., Hallar, B., \& Westmaas, L. (2014). Blended Learning: Defining Models and Examining Conditions to Support Implementation. PERC (Philadelphia Education Research Consortium) Research Brief. Research for Action: Philadelphia, PN.

Bernard, R., Borokhovski, E., Schmid, R., Tmim, R., \& Abrami, P. (2014). A meta-analysis of blended learning and technology use in higher education: from the general to the applied. Journal of Computers in Higher Education, 26, 87-122. https://doi.org/10.1007/s12528013-9077-3

Broadbent, J., \& Poon, W. (2015). Self-regulated learning strategies \& academic achievement in online higher education learning environments: A systematic review. Internet and Higher Education, 27, 1-13. https://doi.org/10.1016/j.iheduc.2015.04.007

Barry Burciul, Kim Kerr. (2018). Case study: education in support of social transformationthe Mastercard Foundation Scholars Program. In Joan R. Dassin, Robin Marsh, Matt Mawer (Eds.), International Scholarships in Higher Education, Palgrave Macmillan, Cham, Switzerland, 329-343. https://doi.org/10.1007/978-3-319-62734-2_16

Chankseliani, M., Qoraboyev, I., \& Gimranova, D. (2021). Higher education contributing to local, national, and global development: new empirical and conceptual insights. High Educ, 81, 109-127. https://doi.org/10.1007/s10734-020-00565-8

Darvas et al. (2017). Peter Darvas, Shang Gao, Yijun Shen, Bilal Bawany. Sharing Higher Education's Promise beyond the Few in Sub-Saharan Africa. Directions in Development World Bank Group, Washington, DC (2017). License: Creative Commons Attribution CC 
BY 3.0 IGO. https://doi.org/10.1596/978-14648-1050-3

Figlio, D., Rush, M., \& Yin, L. (2013). Is it Live or is it Internet? Experimental Estimates of the Effects of Online Instruction on Student Learning. Journal of Labor Economics, 31(4), 763-784. https://doi.org/10.1086/669930

Forbes. (2020). How the World Became Data-Driven, and What's Next. Retrieved from www.forbes.com. https://www.forbes.com/sites/googlecloud/2020/05/20/how-the-worldbecame-data-driven-and-whats-next/?sh=3ac5ec0357fc

Glaeser, E. (2007). Why does democracy need education? Harvard University. Retrieved from https://scholar.harvard.edu/files/glaeser/files/democracy_final_jeg_1.pdf

Graham, C. R. (2006). Blended Learning Systems. Definition, current trends, and Future Directions. In J. Curtis, Ch. Bonk y R. Graham (Ed.), The Handbook of Blended Learning: Global Perspectives, Local Designs. John Wiley \& Sons.

Graham, C. R. (2013). Emerging practice and research in blended learning. In M. G. Moore (Ed.), Handbook of distance education (3rd ed.), 333-350. New York, NY: Routledge. https://doi.org/10.4324/9780203803738.ch21

Heinsen, M., \& Cruz, R. (2012). Factores claves en el establecimiento de e-learning: Experiencia UNIBE. Manuscript.

Ibáñez, J., Garcías, A., \& Cervera, M. (2018). Blended learning, más allá de la clase presencial. RIED. Revista Iberoamericana de Educación a Distancia, 21(1), 195-213. https://doi.org/10.5944/ried.21.1.18859

ITU (International Telecommunication Union). (2018). Measuring the Information Society Report, 2: ICT Country Profiles. Geneva, Switzerland: ITU.

Johnson, D. (2019). Blockchain-based voting in the US and EU constitutional orders: A digital technology to secure democratic values? European Journal of Risk Regulation: EJRR, 10(2), 330-358. http://dx.doi.org/10.1017/err.2019.40

Kamarianos, I., \& Katsillis, M., \& Zorbas, V. (2017). Higher Education and Democracy: a work in progress. Academia, 9, 1-5.

Lange, G-M., Quentin, W., \& Kevin, C., eds. (2018). The Changing Wealth of Nations 2018: Building a Sustainable Future. Washington, DC: World Bank. https://doi.org/10.1596/978-1-4648-1046-6

Mazara, F. (2017). El computador como determinante del acceso an Internet en hogares de la República Dominicana. Ciencia, Economía \& Negocios, 1(1), 40-83. https://doi.org/10.22206/ceyn.2017.v1i1.pp39-85

Means, B., Toyama, Y., Murphy, R., Bakia, M., \& Jones, K. (2010). Evaluation of EvidenceBased Practices in Online Learning: A Meta-Analysis and Review of Online Learning Studies. US Department of Education: Washington, D.C. 
MESCYT (2017). Departamento de Estadística del MESCYT. Informes General sobre Estadísticas de Educación Superior, 2012, 2013-2014, 2015, 2016 y 2017, y recolecciones estadísticas de las IES 2018. b) Estimaciones y Proyecciones Nacionales de Población 1950-2100, 2014. Oficina Nacional de Estadística (ONE), actualizada 1 diciembre 2014.

MSP (Ministerio de Salud Pública). (2020). Retrieved from https://www.msp.gob.do/web/?p=7599

Miniwatts Marketing Group. (2018). Internet World Stats: Usage and Population Statistics. Retrieved from https://www.internetworldstats.com/carib.htm

Navarro Ibarra, L., Salazar, O., \& Castillo, J. (2017). A Meta-Analysis of ICT-Based Education in Mexico y Latin America. Redie (Revista Electrónica de Investigación Educativa), 19(1), 10-20. https://doi.org/10.24320/redie.2017.19.1.1217

OECD (Organization for Economic Cooperation and Development). (2015). E-Learning in Higher Education in Latin America. Chapter 3. (Paris: OECD Development Centre).

Peralta, M. (2009). La educación a distancia en la República Dominicana: situación actual y desafíos futuros. Educación Superior, VIII (1-2), 39-71.

Perna, W. L., Kata, O., Bryan, G., Zakir, J., Adil, A., \& Marina, K. (2014). Promoting human capital development: a typology of international scholarship programs in higher education. Educ. Res., 43(2), 63-73. https://doi.org/10.3102/0013189X14521863

Rama, C., \& Vallejo, M. (2015). La metamorfosis de la educación a distancia en américa latina. una nueva fase marcada por el ingreso de proveedores internacionales. Revista Española de Educación Comparada, 26(2015), 41-60. https://doi.org/10.5944/reec.26.2015.15810

Sánchez, D., Solís, M., \& Martos, I. (2018). Vídeo educativo y rendimiento académico en la enseñanza superior a distancia. RIED. Revista Iberoamericana de Educación a Distancia, 21(1), 323-341. https://doi.org/10.5944/ried.21.1.18326

San, C. M., Martin, D., Navarro, A. E., \& Tourón, J. (2017). Flipped classroom y didáctica de las matemáticas en la formación online de maestros de Educación Infantil Revista Electrónica. Interuniversitaria de Formación del Profesorado, 20(3), 1-14. https://doi.org/10.6018/reifop.20.3.292551

SEESCYT. (2006). Reglamento de Instituciones y Programas de Educación Superior a Distancia. Santo Domingo: Secretaría de Educación Superior, Ciencia y Tecnología.

Staker, H., \& Horn, M. (2012). Classifying K-12 Blended Learning. Innosight Institute: Boston, MA.

The Economist. (2020). A rare power shift: The Dominican Republic changes its ruling party. Retrieved from https://www.economist.com/the-americas/2020/07/08/the-dominicanrepublic-changes-its-ruling-party

Thomas, N. (2017). The Evolving Role of Higher Education in U.S. Democracy. Retrieved from www.ejournalofpublicaffairs.org 
UNESCO. (2018). Retrieved from http://uis.unesco.org/apps/visualisations/research-anddevelopment-spending/

United Nations, (2019). United Nations. "Population." n.d. Retrieved from http://www.un.org/en/sections/issues-depth/population/. Accessed November 18, 2018.

World Bank. (2017). Policy Research Working Paper. In the Mind, the Household, or the Market? Concepts and Measurement of Women's Economic Empowerment. Retrieved from

http://documents1.worldbank.org/curated/en/436011496234827185/pdf/WPS8079.pdf

World Bank. (2018). World Development Indicators Database. Retrieved from https://data.worldbank.org/country/dominican-republic

World Bank. (2021). Skills Development. Retrieved from https://www.worldbank.org/en/topic/skillsdevelopment

Xu, D., \& Jaggars, S. (2014). Performance Gaps Between online and Face-to-face Courses: Differences across Types of Students and Academic Subject Areas. The Journal of Higher Education, 25(5), 633-659. https://doi.org/10.1353/jhe.2014.0028

\section{Copyrights}

Copyright for this article is retained by the author(s), with first publication rights granted to the journal.

This is an open-access article distributed under the terms and conditions of the Creative Commons Attribution license (http://creativecommons.org/licenses/by/4.0/) 